\title{
Arboreal nesting and utilization of open-cup bird nests by introduced Ship Rats Rattus rattus on an oceanic island
}

\author{
SHIN MATSUI, MARIKO HISAKA and MASAOKI TAKAGI
}

\begin{abstract}
Summary
The introduction of exotic rats Rattus spp. is one of the most important factors contributing to the reduction in avian diversity and extinctions on oceanic islands. However, little is known about factors other than predation, which are associated with the loss of island biodiversity. We report that introduced Ship Rats Rattus rattus constructed arboreal dome-shaped nests and secondarily used open-cup nests of the Bull-headed Shrike Lanius bucephalus for roosting or rearing young in trees within hedgerows along sugarcane fields of Minami-daito Island (northwest Pacific). We found that temporal nest utilization by Ship Rats forced Bull-headed Shrikes to abandon their nests before egg-laying. We suggest that kleptoparasitism applies to the interaction between Bull-headed Shrikes and Ship Rats, which usurp shrike nests during their breeding period. It is necessary to consider the potential effects of introduced Ship Rats on insular avian communities not only through predation but also through interspecific interaction over nest-sites.
\end{abstract}

\section{Introduction}

The introduction of exotic animals is one of the most important factors contributing to the reduction in biological diversity and extinctions on oceanic islands (Coblentz 1990, Dobson and Foufopoulus 2001, Steadman 2006). Exotic animals can damage native species both directly and indirectly through mechanisms such as predation, the introduction of disease and interspecific competition (Eguchi and Amano 2004, Gurnell et al. 2004, Smith and Carpenter 2006, Kurle et al. 2008). In particular, exotic rat species, including Brown Rats Rattus norvegicus, Ship Rats $R$. rattus and Pacific Rats $R$. exulans, have now reached more than $80 \%$ of the world's oceanic islands and island groups (Atkinson 1985). Major declines or extinctions of endemic forest birds followed the invasion and spread of Ship Rats on Lord Howe Island and the Hawaiian Islands (Hindwood 1940, Recher and Clark 1974, Atkinson 1977). Campbell (1991) suggested that the abundance of introduced Ship Rats might adversely affect the diversity of avian communities on seven islands of the Antillean Cays. Predation by Rattus spp. is considered a major cause of avian extinction in insular habitats (King 1985). However, little is known about factors related to rats other than predation, which are associated with the reduction in the bird diversity of islands. Introduced Ship Rats flexibly used burrows, nest boxes or tree holes to rest or breed in a wide range of habitats, such as coastal areas, cultivated land and forests (Barba and Gil-Delgado 1990, Tobin et al. 1996, Pye et al. 1999, Lambrechts et al. 2007, Whisson et al. 2007). Accordingly, introduced Ship Rats have the potential to affect insular avian communities not only through predation but also through interspecific competition for nesting sites in various environments.

Ship Rats were considered to have arrived with building materials for a sugar plant on oceanic Minami-daito Island in the northwest Pacific in 1917 (Editorial Committee of the History of 
Minami-daito Village 1990). In this paper, we document the construction of arboreal domeshaped nests in trees in hedgerows along sugarcane fields and the utilization of open-cup Bullheaded Shrike Lanius bucephalus nests for roosting or rearing the young by Ship Rats on Minami-daito Island. Nest-site characteristics of Ship Rats in the hedgerows raise the possibility of overlap with arboreal nesting bird species, i.e. the Brown-eared Bulbul Ixos amaurotis (synonym Hypsipetes amaurotis borodinonis; Ornithological Society of Japan 200o) and the Bull-headed Shrike. We therefore investigated the overlap of nest-site characteristics among these three species in an agricultural habitat. We also quantified the frequency with which rats remodelled the open-cup nests of bulbuls and shrikes.

\section{Methods}

The study was conducted on Minami-daito Island $\left(25^{\circ} 50^{\prime} \mathrm{N}, 131^{\circ} 14^{\prime} \mathrm{E}, 30.57 \mathrm{~km}^{2}\right.$ in area) between February and August in each of the years 2002-2006. Minami-daito is an oceanic island located in the northwest Pacific c. $360 \mathrm{~km}$ east of Okinawa Island. Most forest cover was removed after humans settled there in 1900, and agricultural fields, mainly sugarcane Saccharum officinarum, now cover c. $60 \%$ of the island. Hedgerows composed of Alexandrian Laurel Calophyllum inophyllum and Garcinia Garcinia subelliptica trees function as windbreaks in the fields. The agricultural landscape is homogeneous due to the limited range of vegetation and its simple structure.

The Brown-eared Bulbul of the Daito Islands is an endemic subspecies (Ornithological Society of Japan 2000), and there have been naturally established populations of Bull-headed Shrikes on Minami- and Kita-daito islands since the 1970 (Takagi 2000, Matsui et al. 2006). To describe the arboreal nesting and utilization of open-cup bird nests by Ship Rats, we searched for and observed nests of Ship Rats, Brown-eared Bulbuls and Bull-headed Shrikes in the hedgerows along the sugarcane fields. Since we have not observed them re-use previously constructed nests, we considered that Brown-eared Bulbuls and Bull-headed Shrikes build new nests at each breeding attempt, like other open-nesting passerines (see Friesen et al. 1999; Marshall et al. 2001). To quantify the frequency with which rats remodelled bird nests, between 4 and 16 August 2005, we revisited all bulbul and shrike nests that we had found in 2005 and checked whether these nests had been remodelled by Ship Rats. Shrike nests were monitored every 3-6 days until the nest fledged or failed. We measured nests to compare their shapes among Ship Rats, Brown-eared Bulbuls and Bull-headed Shrikes. Measurements included nesting height (from ground to nest base), nest cup width and length (wall-to-wall inside the oval nest), cup depth (from rim level to the bottom of the cup), nest width and length (wall-to-wall outside the oval nest), exterior nest height (from nest base to cup lip) and bottom thickness (exterior nest height minus cup depth). For dome-shaped nests with an entrance at the side, we also measured the entrance width and length. We recorded nest tree species and measured the height and diameter at breast height $(\mathrm{dbh})$ of the nest tree. All data are expressed as mean $\pm \mathrm{SD}(n)$ unless noted otherwise.

\section{Results}

\section{Arboreal nesting of Ship Rats}

We observed three breeding attempts of Ship Rats on trees in hedgerows along the sugarcane fields in 2002 and 2005. The first breeding attempt was made in a dome-shaped nest on a Garcinia tree in a hedgerow along the sugarcane field. One adult rat and more than two naked rat pups emerged from the nest on 9 May 2002. It was inferred that the rats had constructed the nest because we had never seen such a dome-shaped bird nest on Minamidaito Island.

The second breeding attempt was made in a remodelled Bull-headed Shrike nest. One adult rat and two young rats emerged from the nest (nest tree species Casuarina equisetifolia; nesting 
height, $406 \mathrm{~cm}$; nest tree height, 1,255 cm; dbh, $39 \mathrm{~cm}$ ) on 8 August 2005. The first shrike egg was laid in the nest in early March 2005, and all the eggs were depredated during the incubation period. When we found the three rats on 8 August 2005, the nest had been repositioned on its side and the materials of the nest-cup had been brought out of the nest and used to elongate the entrance. In addition, the opening of the nest-cup was narrowed and shaded with dead horsetail leaves. The nest was dome-shaped.

The third probable breeding attempt was also made in a remodelled Bull-headed Shrike nest. Two adult rats emerged from a used Bull-headed Shrike nest (nest tree species, Alexandrian Laurel; nesting height, $328 \mathrm{~cm}$; nest tree height, $824 \mathrm{~cm}$; DBH, $27 \mathrm{~cm}$ ) on 3 June 2005. The first shrike egg was laid in the nest on II February 2005, and the nestlings were depredated by a Japanese Weasel Mustela itatsi in late March. An adult rat was found in the nest when we inspected the nest on 4 July. The nest was dome-shaped with an entrance in the side. Chips $(1-2 \mathrm{~cm})$ of green leaves of Alexandrian Laurel were found in the nest cup.

\section{Nest usurpation by Ship Rats}

We found that rats usurped shrike nests without signs of remodelling. We observed rats sitting in two shrike nests during the pre-laying period in 2006, and the shrikes subsequently abandoned these nests, but the two nests had not been remodelled when we re-checked the nests on 10 and 11 July 2006, respectively.

\section{Remodelling of open-cup bird nests by Ship Rats}

We found 8 rat nests, 11 bulbul nests and 193 shrike nests in 2005 (Figure $1 \mathrm{a}-\mathrm{c}$ ). We examined whether 10 bulbul nests and 128 shrike nests were remodelled by Ship Rats. No bulbul nests $(n=10)$ and $22.7 \%(29 / 128)$ of the shrike nests were remodelled. The shapes of the 29 remodelled shrike nests were classified into the following three types: (I) materials brought out of the nest-cup (Figure $1 d, 51.7 \%, n=15$ ); (2) rotated to a more horizontal orientation (Figure 1e, $10.3 \%, n=3$ ); (3) remodelled into a dome shape (Figure $1 \mathrm{f}, 37.9 \%, n=11$ ).

Out of the 29 remodelled shrike nests, four (13.8\%) were remodelled after breeding failure unrelated to Ship Rats, and three (10.3\%) were remodelled after the shrike nestlings had fledged. We found pieces of eggshells in two remodelled shrike nests $(6.9 \%)$, and inferred that Ship Rats had remodelled the nests after egg depredation. We could not determine the breeding stages in which 20 nests $(69.0 \%)$ were remodelled.

\section{Nest shape and materials}

Ship Rats built dome-shape nests (Figure ra) and Brown-eared Bulbuls and Bull-headed Shrikes constructed open-cup nests on branches (Figure $\mathrm{Ib}, \mathrm{Ic}$ ). We investigated the nest materials in two rat nests. Rat nests were composed of only Poaceae plant leaves that were more than $1 \mathrm{~cm}$ wide (e.g. sugarcane or Chinese Silvergrass Miscanthus sinensis). Entrances to the dome-shaped nests were concealed by c. 4-8 ears of Chinese Silvergrass (Figure 1a). Shrike nests that had been remodelled into dome shapes were significantly larger than non-remodelled shrike nests (Table 1 ). The shapes of bulbul and shrike nests were very similar to each other (Figure $1 b, c$ ), but the bottom of shrike nests was significantly thicker than that of bulbul nests (Table 1 ). The mean weights of bulbul and shrike nests were $19.9 \pm 2.9 \mathrm{~g}(n=3)$ and $22.8 \pm 4.3 \mathrm{~g}(n=3)$, respectively. We could separate nest materials of bulbuls and shrikes into nest-cup and other materials. The weight of the nest-cup material of shrikes $(7.4 \pm 0.5 \mathrm{~g})$ was approximately two times that of the bulbul nest-cup material ( $3.6 \pm 1.2 \mathrm{~g})$; the weights of the other materials were similar for bulbuls $(16.3 \pm 3.3 \mathrm{~g})$ and shrikes (15.3 $\pm 4.1 \mathrm{~g})$. 

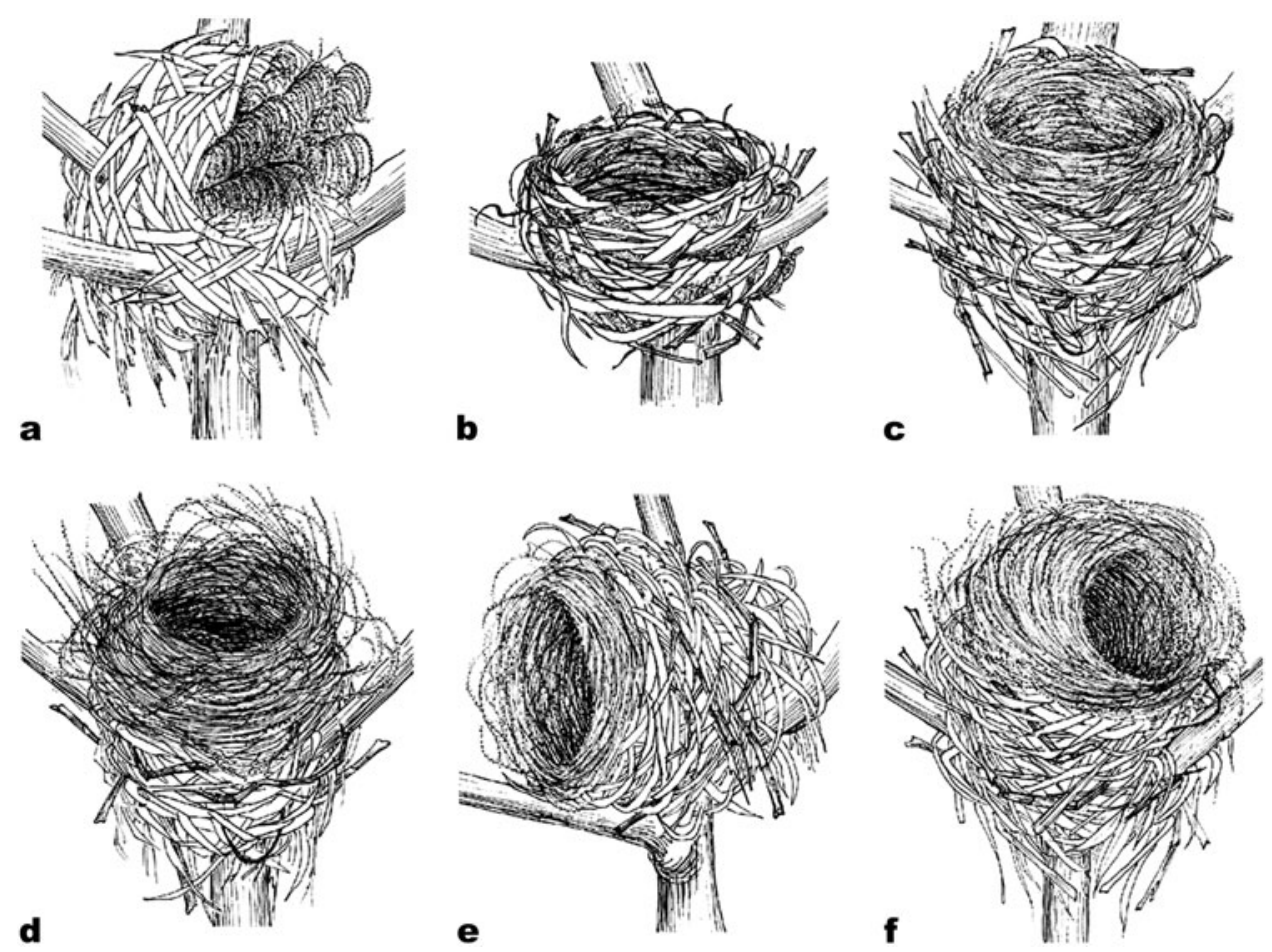

Figure 1. (a) Ship Rat nest. (b) Brown-eared Bulbul nest. (c) Bull-headed Shrike nest. (d) Shrike nest reshaped by removal of materials from nest-cup. (e) Repositioned shrike nest. (f) Shrike nest remodelled into a dome shape.

\section{Overlap of nest-site characteristics}

The nesting tree species are shown in Table 2. Out of the five nesting tree species of Ship Rats, $40 \%$ and $80 \%$ of tree species were used by Brown-eared Bulbuls and Bull-headed Shrikes for nesting, respectively. Nesting height from the ground to the base of the nest differed significantly among rat nests $(309 \pm 87 \mathrm{~cm}$, range $222-475 \mathrm{~cm}, n=8)$, bulbul nests $(493 \pm 187 \mathrm{~cm}$, range 221$824 \mathrm{~cm}, n=10)$, remodelled shrike nests $(295 \pm 154 \mathrm{~cm}$, range $111-641 \mathrm{~cm}, n=28)$ and nonremodelled shrike nests $(319 \pm 155 \mathrm{~cm}$, range $129-792 \mathrm{~cm}, n=97)$ (Kruskal-Wallis test, $H=9.93, \mathrm{df}=3, P=0.019)$. In contrast, nesting height did not differ significantly between bulbuls and rats (Mann-Whitney test, $U=14.0, Z=-2.31, P=0.021$, but $P>0.05$ with sequential Bonferroni correction according to Rice 1989), bulbul nests were significantly higher than remodelled shrike nests $(U=53.0, Z=-2.88, P=0.003, P<0.05$ with Bonferroni correction) and non-remodelled shrike nests $(U=216.5, Z=-2.87, P=0.004, P<0.05$ with Bonferroni correction). The height of the nesting tree did not vary significantly among rat nests $(649 \pm 195 \mathrm{~cm}$, range $389-923 \mathrm{~cm}, n=8)$, bulbul nests $(810 \pm 263 \mathrm{~cm}$, range $438-1,311 \mathrm{~cm}$, $n=11)$, remodelled shrike nests $(606 \pm 281 \mathrm{~cm}$, range $255-1,255 \mathrm{~cm}, n=28)$ and nonremodelled shrike nests $(678 \pm 310 \mathrm{~cm}$, range $226-1,838 \mathrm{~cm}, n=97)$ (Kruskal-Wallis test, $H=4.65, \mathrm{df}=3, P=0.199$ ). DBH also did not vary significantly among rat nests ( $15 \pm 10 \mathrm{~cm}$, range 6 $-34 \mathrm{~cm}, n=8)$, bulbul nests $(20 \pm 9 \mathrm{~cm}$, range $5-7 \mathrm{~cm}, n=11$ ), remodelled shrike nests $(16 \pm 12 \mathrm{~cm}$, range $3-47 \mathrm{~cm}, n=28)$ and non-remodelled shrike nests (19 $\pm 14 \mathrm{~cm}$, range $1-93 \mathrm{~cm}$, $n=97)$ (Kruskal-Wallis test, $H=2.52, \mathrm{df}=3, P=0.471$ ). 
Table 1. Dimensions of (A) Ship Rat nests, (B) Bull-headed Shrike nests remodelled by ship rats into a dome shape, (C) non-remodelled Bull-headed Shrike nests and (D) Brown-eared Bulbul nests in 2005.

\begin{tabular}{|c|c|c|c|c|c|c|c|}
\hline \multirow[t]{2}{*}{$\begin{array}{l}\text { Measurements } \\
(\mathrm{mm})\end{array}$} & \multirow[t]{2}{*}{$\begin{array}{l}\text { A. Rat } \\
(n=2\end{array}$} & & \multirow[t]{2}{*}{$\begin{array}{l}\text { B. rmd Shrike } \\
\quad(n=5)\end{array}$} & \multirow[t]{2}{*}{$\begin{array}{l}\text { C. non-rmd } \\
\text { Shrike } \\
(n=22)\end{array}$} & \multirow[t]{2}{*}{$\begin{array}{l}\text { D. Bulbul } \\
(n=7)\end{array}$} & \multicolumn{2}{|c|}{$\begin{array}{l}\text { Mann- } \\
\text { Whitney } \\
\text { U test }\end{array}$} \\
\hline & & & & & & $\mathrm{B}-\mathrm{C}$ & $\mathrm{C}-\mathrm{D}$ \\
\hline Cup length & 112 & 84 & $104 \pm 20(76-125)$ & $87 \pm 4(78-94)$ & $88 \pm 15(73-116)$ & $*$ & ns \\
\hline Cup width & 73 & 98 & $93 \pm 7(85-102)$ & $73 \pm 9(46-88)$ & $75 \pm 6(66-84)$ & $* *$ & ns \\
\hline Cup depth & 41 & 59 & $76 \pm 8(66-87)$ & $45 \pm 4(39-51)$ & $45 \pm 11(36-68)$ & $* *$ & ns \\
\hline Nest length & 139 & 163 & $152 \pm 26(113-176)$ & $129 \pm 9(106-147)$ & $131 \pm 13(111-154)$ & ns & ns \\
\hline Nest width & 129 & 172 & $130 \pm 16(114-151)$ & $114 \pm 12(83-135)$ & $115 \pm 8(103-123)$ & $*$ & ns \\
\hline $\begin{array}{l}\text { Exterior nest } \\
\text { height }\end{array}$ & 83 & 109 & $105 \pm 1(104-107)$ & $78 \pm 10(57-95)$ & $66 \pm 9(54-77)$ & $* *$ & $* *$ \\
\hline $\begin{array}{l}\text { Bottom } \\
\text { thickness }\end{array}$ & - & - & - & $34 \pm 10(17-55)$ & $21 \pm 7(9-28)$ & - & $* *$ \\
\hline $\begin{array}{l}\text { Entrance } \\
\text { length }\end{array}$ & 20 & 36 & $41 \pm 6(36-47)$ & - & - & - & - \\
\hline $\begin{array}{c}\text { Entrance } \\
\text { width }\end{array}$ & 24 & 32 & $45 \pm 12(36-65)$ & - & - & - & - \\
\hline
\end{tabular}

ns $P>0.05,{ }^{*} P<0.05,{ }^{*} P<0.01$, A measured values; $B-D$ mean $\pm \mathrm{SD}$ (max-min).

\section{Discussion}

On Minami-daito Island, Ship Rats constructed dome-shaped nests in trees in hedgerows along sugarcane fields and utilized open-cup bird nests to breed. Arboreal dome-shaped nests, as well as tree-cavity nests of Ship Rats, were also observed in Mauritius (L. Woolaver pers. comm.). Ship Rats have been recorded using nest boxes filled with leaves, mainly to rest but occasionally to breed, in eastern Spain (Barba and Gil-Delgado 1990). Lambrechts et al. (2007) observed Ship Rats building a nest on top of unfinished nests of Blue Tits Parus caeruleus and Great Tits

Table 2. Nest tree species of Ship Rats, Brown-eared Bulbuls, and Bull-headed Shrikes on Minami-daito Island in 2005.

\begin{tabular}{|c|c|c|c|c|c|c|}
\hline \multirow[t]{2}{*}{ Nest tree species } & \multicolumn{2}{|c|}{ Ship Rat } & \multicolumn{2}{|c|}{$\begin{array}{l}\text { Brown-eared } \\
\text { Bulbul }\end{array}$} & \multicolumn{2}{|c|}{$\begin{array}{l}\text { Bull-headed } \\
\text { Shrike }\end{array}$} \\
\hline & $n$ & $\%$ & $n$ & $\%$ & $n$ & $\%$ \\
\hline Calophyllum inophyllum & 4 & 50 & 4 & 36.4 & 66 & 52.8 \\
\hline Casuarina equisetifolia & - & - & 1 & 9.1 & 16 & 12.8 \\
\hline Garcinia subelliptica & 1 & 12.5 & - & - & 14 & 11.2 \\
\hline Morus australis & 1 & 12.5 & - & - & 10 & 8 \\
\hline Ficus virgata & 1 & 12.5 & 1 & 9.1 & 6 & 4.8 \\
\hline Leucaena leucocephala & - & - & - & - & 5 & 4 \\
\hline Ficus microcarpa & - & - & 2 & 18.2 & 4 & 3.2 \\
\hline Ficus erecta & - & - & - & - & 1 & 0.8 \\
\hline Cerbera manghas & - & - & - & - & 1 & 0.8 \\
\hline Carmona retusa & - & - & - & - & 1 & 0.8 \\
\hline Pinus luchuensis & - & - & 2 & 18.2 & 1 & 0.8 \\
\hline Diospyros maritima & - & - & 1 & 9.1 & - & - \\
\hline Bambusa sp. & 1 & 12.5 & - & - & - & - \\
\hline Total & 8 & 100 & 11 & 100 & 125 & 100 \\
\hline
\end{tabular}


P. major in nest boxes. However, we could not find records showing that Ship Rats bred in remodelled open-cup bird nests. In contrast, the construction of arboreal nests by Ship Rats is considered to be common, but nest sites of Ship Rats for breeding have not been sufficiently described in the wild.

Introduced Ship Rats have the ability to use a wide range of spaces, including the ground and trees, in different habitat types, e.g. forest, grasslands and orchards (Dowding and Murphy 1994, Hooker and Innes 1995, Tobin et al. 1996, Pye et al. 1999, Whisson et al. 2007). Radio-tracked Ship Rats were mostly arboreal in tall (up to $30 \mathrm{~m}$ ) forests in New Zealand (Hooker and Innes 1995). Whisson et al. (2007) observed Ship Rats using tree hollows at heights of $2 \mathrm{~m}$ or more as daytime dens in an old-growth riparian forest in California. However, in the tall-tussock grassland on Macquarie Island, Ship Rats excavated burrows and constructed nesting chambers at the base of tussock shoots (Pye et al. 1999). In a Hawaiian Macadamia Macadamia integrifolia orchard, cultivated on a lava rock substrate with subterranean cracks and crevices, most Ship Rats remained in burrows during the day and ascended into the canopies of the macadamia trees during the night to feed on nuts (Tobin et al. 1996). Arboreal open-cup bird nests would be valuable to Ship Rats for resting or nesting in the agricultural landscape of Minami-daito Island, because Alexandrian Laurel and Garcinia trees without cavities are dominant in the hedgerows, and because potential predators of rats - introduced Japanese Weasels and feral cats Felis catus search for food on the ground.

There are several possible structural or ecological reasons why Ship Rats use shrike nests to breed: (1) shrike nests have more structural stability than rat nests; (2) shrike nests are of a suitable size for rats; and (3) Ship Rats and Bull-headed Shrikes overlap considerably in nesting height preference. We did not observe any bulbul nests remodelled by Ship Rats. It might be difficult for rats to enlarge bulbul nests because only a few dead coniferous leaves were found in the nest-cups (Figure $\mathrm{Ib}$ ), and the bottoms of bulbul nests were significantly thinner than those of shrike nests (Table 2). Moreover, there would be little overlap of nest-site characteristics between bulbuls and rats because nesting height of bulbuls was somewhat higher than that of rats; the difference was not significant, however, perhaps because of the small sample size.

The overlap of nesting height between Ship Rats and Bull-headed Shrikes was larger than between the rats and Brown-eared Bulbuls. This similarity of nest sites between rats and shrikes is inferred to reflect the overlapping of their ecological niches. The overlap of nesting sites would have the following negative effects on shrikes: (I) the risk of nest predation by Ship Rats would increase, which is supported by the evidence that Ship Rats caused at least $70 \%$ of egg predation and $20 \%$ of nestling predation of Bull-headed Shrikes on Minami-daito Island (S.M. and M.T., unpublished data); (2) the risk of nest usurpation by Ship Rats would increase, because several researchers have shown that Ship Rats use between two and nine dens during the daytime and some individuals change den sites frequently (Dowding and Murphy 1994, Whisson et al. 2007); and (3) competition for food resources between Ship Rats and Bull-headed Shrikes, both of which feed on invertebrates, e.g. grasshoppers, locusts, cockroaches and spiders, would be intensified (Innes 2001).

Introduced species may reduce the number of native birds through interspecific competition for nest sites (Kerpez and Smith 1990, Ingold 1994). Birds and mammals seeking nest sites interact through exploitation competition and kleptoparasitism (Sarà et al. 2005, Lambrechts et al. 2007, Kappes and Davis 2008). An example of the effect of exploitation competition is the occupation of nest boxes by Ship Rats, which decreased the use of boxes by Great Tits (Barba and GilDelgado 1990, Lambrechts et al. 2007). Kappes (1997) argues that heterospecific usurpation of cavities excavated by woodpeckers is appropriately described as cavity kleptoparasitism, because the interaction is negative for woodpeckers and beneficial for cavity usurpers. In North America, Southern Flying-squirrels Glaucomys volans are seen as major predators or cavity kleptoparasites of nesting Red-cockaded Woodpeckers Picoides borealis (Ligon 1970, Rudolph et al. 1990, Kappes and Davis 2008). We found that temporal nest utilization by Ship Rats forced Bullheaded Shrikes to abandon their nests before egg-laying. We suggest that kleptoparasitism applies to the interaction between Bull-headed Shrikes and Ship Rats, which usurp their arboreal 
open-cup nests, because the interaction is negative for Bull-headed Shrikes and beneficial for Ship Rats. Invasive Common Starling Sturnus vulgaris usurped the nesting cavities of native birds and reduced their fecundity (Ingold 1989, 1994). Nest usurpation by Ship Rats, as well as by introduced Common Starlings, has the potential to reduce the fitness of shrikes by increasing the cost of re-nesting, delaying breeding and decreasing the number of broods reared. With regard to the conservation of birds on an island with Ship Rats, which are able to use burrows, nest boxes, tree holes and open-cup bird nests to rest or breed in a wide range of habitats, it is necessary to consider the potential effects of introduced rats on avian communities not only through predation but also through nest-site competition and nest kleptoparasitism.

\section{Acknowledgements}

We are deeply indebted to Kiyoshi Asanuma, Kazuaki Higashi, Mitsunori Okuyama and members of the board of education of Minami-daito village for kindly supporting our fieldwork. We thank Kana Akatani for making the sketch of rat and bird nests in Figure 1 . We are grateful to Kazuhiro Eguchi and Naoki Tomita for valuable comments on the drafts of the manuscript. We appreciate the improvements in English usage made by Caitlin Stern through the Association of Field Ornithologists' program of editorial assistance. This manuscript was greatly enhanced by constructive comments from Lance Woolaver and an anonymous reviewer.

\section{References}

Atkinson, I. A. E. (1977) A reassessment of factors, particularly Rattus rattus L., that influenced the decline of endemic forest birds in the Hawaiian Islands. Pac. Sci. 31: 109-133.

Atkinson, I. A. E. (1985) The spread of commensal species of Rattus to oceanic islands and effects on island avifaunas. Pp. 35-8I in P. J. Moors, ed. Conservation of island birds. Cambridge, UK: International Council for Bird Preservation. Tech. Publ. No. 3.

Barba, E., Gil-Delgado, J. A. (1990) Competition for nest-boxes among four vertebrate species: an experimental study in orange groves. Holarctic Ecol. 13: 183-186.

Campbell, E. W. (1991) The effect of introduced roof rats on bird diversity of Antillean Cays. J. Field Ornithol. 62: 343-348.

Coblentz, B. E. (1990) Exotic organisms: a dilemma for conservation biology. Conserv. Biol. 4: 261-265.

Dobson, A. P. and Foufopoulus, J. (2001) Emerging infectious pathogens of wildlife. Phil. Trans. R. Soc. Lond. B 356: 1001-1012.

Dowding, J. E. and Murphy, E. C. (1994) Ecology of Ship Rats (Rattus rattus) in a kauri (Agathis australis) forest in
Northland, New Zealand. New Zeal. J. Ecol. 18: 19-28.

Editorial Committee of the History of Minami-daito Village (1990) The history of Minami-daito village, a revised edition. Naha, Japan: Minamidaito village office (in Japanese).

Eguchi, K. and Amano, H. E. (2004) Spread of exotic birds in Japan. Ornithol. Sci. 3: 3-11.

Friesen, L. E., Wyatt, V. E. and Cadman, M. D. (1999) Nest reuse by Wood Thrushes and Rose-breasted Grosbeaks. Wilson Bull. 111: 132-133.

Gurnell, J., Wauters, L. A., Lurz, P. W. W. and Tosi, G. (2004) Alien species and interspecific competition: effects of introduced eastern grey squirrels on red squirrel population dynamics. J. Anim. Ecol. 73: 26-35.

Hindwood, K. A. (1940) The birds of Lord Howe Island. Emu 40: 1-86.

Hooker, S. and Innes, J. (1995) Ranging behaviour of forest-dwelling Ship Rats, Rattus rattus, and effects of poisoning with brodifacoum. New Zeal. J. Zool. 22: 291304.

Ingold, D. J. (1989) Nesting phenology and competition for nest sites among 
Red-headed and Red-bellied Woodpeckers and European Starlings. Auk 106: 209217.

Ingold, D. J. (1994) Influence of nest-site competition between European Sterlings and Woodpeckers. Wilson Bull. 106: 227241.

Innes, J. (2001) Advances in New Zealand mammalogy 1990-2000: European rats. J. Roy. Soc. New. Zeal. 31: 111-125.

Kappes, J. J. Jr. (1997) Defining cavity-associated interactions between Red-cockaded Woodpeckers and other cavity-dependent species: interspecific competition or cavity kleptoparasitism? Auk 114: 778-780.

Kappes, J. J. Jr. and Davis, J. M. (2008) Evidence of positive indirect effects within a community of cavity-nesting vertebrates. Condor 110: 441-449.

Kerpez, T. A. and Smith, N. S. (1990) Competition between European Starlings and native woodpeckers for nest cavities in saguaros. Auk 107: 367-375.

King, W. P. (1985) Island birds: will future repeat the past? Pp. 3-15 in P. J. Moors, ed. Conservation of island birds. Cambridge, UK: International Council for Bird Preservation. Technical Publication No. 3.

Kurle, C. M., Croll, D. A. and Tershy, B. R. (2008) Introduced rats indirectly change marine rocky intertidal communities from algae- to invertebrate-dominated. P. Natl. Acad. Sci. USA 105: 3800-3804.

Lambrechts, M. M., Bourgault, P., Mennerat, A., Galan, M.-J., Cartan-Son, M., Perret, P., Doutrelant, C. and Charmantier, A. (2007) Cavity-nesting black rats in distinct Corsican oak habitats and their potential impact on breeding Paridae. Folia Zool. 56: 445448.

Ligon, J. D. (1970) Behavior and breeding biology of the Red-cockaded Woodpecker. Auk 87: 255-278.

Marshall, J. S., Glover, P. A. R., Buechi, K. A. and VanDruff, L. W. (2001) Nest reuse by a Gray Catbird. Wilson Bull. 113: 337338.

Matsui, S., Hisaka, M. and Takagi, M. (2006) Direct impact of typhoons on the breeding activity of Bull-headed Shrike Lanius bucephalus on Minami-Daito Island. Ornithol. Sci. 5: 227-229.
Ornithological Society of Japan (2000) Checklist of Japanese birds. Sixth revised edition. Obihiro, Japan: Ornithological Society of Japan.

Pye, T., Swain, R. and Seppelt, R. D. (1999) Distribution and habitat use of the feral black rat (Rattus rattus) on subantarctic Macquarie Island. J. Zool. 247: 429438.

Recher, H. F., and Clark, S. S. (1974) A biological survey of Lord Howe Island with recommendations for the conservation of the island's wildlife. Biol. Conserv. 6: 263273.

Rice, W. R. (1989) Analyzing tables of statistical tests. Evolution 43: 223-225.

Rudolph, D. C., Conner, R. N. and Turner, J. (1990) Competition for Red-cockaded woodpecker roost and nest cavities: effects of resin age and entrance diameter. Wilson Bull. 102: 23-36.

Sarà, M., Milazzo, A., Falletta, W. and Bellia, E. (2005) Exploitation competition between hole-nesters (Muscardinus avellanarius, Mammalia and Parus caeruleus, Aves) in Mediterranean woodlands. J. Zool. 265: 347357.

Smith, K. F. and Carpenter, S. M. (2006) Potential spread of introduced black rat (Rattus rattus) parasites to endemic deer mice (Peromyscus maniculatus) on the California Channel Island. Divers. Distrib. 12: $742-748$.

Steadman, D. W. (2006) Extinction and biogeography of tropical Pacific birds. Chicago, IL: University of Chicago Press.

Takagi, M. (2000) Plumage, morphology, distribution and breeding ecology of the Bull-headed Shrike on Minami-daito Island. J. Yamashina Inst. Ornithol. 32: 13-23 (in Japanese with English abstract).

Tobin, M. E., Sugihara, R. T., Koehler, A. E. and Ueunten, G. R. (1996) Seasonal activity and movements of Rattus rattus (Rodentia, Muridae) in a Hawaiian macadamia orchard. Mammalia 60: 3-13.

Whisson, D. A., Quinn, J. H. and Collins, K. C. (2007) Home range and movements of roof rats (Rattus rattus) in an old-growth riparian forest, California. J. Mammal. 88: 589-594. 
SHIN MATSUI*, MARIKO HISAKA, MASAOKI TAKAGI

Department of Biology and Geosciences, Graduate School of Science, Osaka City University, 3-3-138 Sugimoto, Sumiyoshi, Osaka 558-8585, Japan.

*Author for correspondence; e-mail:matsuishin@hotmail.com

Received 19 June 2008; revision accepted 22 February 2009;

Published online 16 October 2009 